Available online at http://jgu.garmian.edu.krd

Journal of University of Garmian

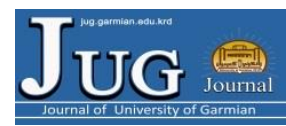

https://doi.org/10.24271/garmian.196226

\title{
Prevalence of head lice, Pediculus humanus capitis L. and their relation to anxiety among primary school children in Kalar district, Kurdistan region-Iraq
}

\author{
Omer M. Amin ${ }^{1}$, Halmat Faieeq D. Mahmood ${ }^{2}$, Awat A. Muhammed ${ }^{3}$, Sawsan A. \\ Huss ein ${ }^{3}$, Layla Q. Mohammed ${ }^{3}$ and Bahar W. Rostam ${ }^{3}$ \\ 1 Biology Department, College of Education, University of Garmian \\ 2 Kindergarten Department, College of Education, University of Garmian \\ 3 Biology Department, College of Education, University of Garmian
}

\section{Article Info}

Received: June, 2019

Revised: June ,2019

Accepted: June ,2019

\section{Keywords}

Head lice, School children, Kalar, Prevalence, Anxiety

Corresponding Author

omer.mahmood@garmian.edu.krd

\begin{abstract}
Abs tract
Head lice, Pediculus humanus capitis De Geer infestation is one of the most important health problems throughout the world. The aim of the current study was to estimate the prevalence of head lice among local primary school children in Kalar district-Kurdistan, Iraq and find out the relationship between head lice infestation and anxiety. During the period October 2018 to May 2019, an overall 8847 primary school children aged (6-11 years) were randomly selected from (22) primary schools and examined for the presence of head lice using lice comb and magnifying lenses. Results of the current study revealed the existence of 1277 cases $(14.43 \%)$ of infestation with $P$. humanus capitis. The rate of infection in girls was significantly higher than boys $\mathrm{P}<0.05$. Schools of the center of Kalar had higher prevalence rate than those of the sub-districts. The highest rate of infection was observed among children aged 10-11 years while the lowest rate was observed in the younger children 6-7 years. Variations in infection rates were observed in the different investigated schools. There was a great correlation between number of students in class and infection rate $\mathrm{P}<0.05$. In addition, the study showed relationship between head lice and anxiety. Accordingly, $66 \%$ of the infested children had moderate anxiety. Findings of this study suggest that head lice infestation is within the epidemic level in Kalar.
\end{abstract}

Introduction

1 Three divergent clades of lice can infest human: Head lice, body lice and pubic lice (Amin and Ameen, 2018). The human head louse, Pediculus humanus Var. capitis De Geer, 1778, is a wingless, blood feeding parasitic insect of human that affect millions of people in different ages particularly children in all over the world (Doroodgar et al., 2011). Head lice are more prevalent in the developing countries especially in the crowded places with low socio-economic and poor hygiene conditions (Akhter et al., 2010). Pediculus humanus capitis lives on the human scalp where it attaches to the hair shafts, nourish on blood and complete all the stages of its life cycle: egg, nymph and adult 
(Meister and Ochsendorf, 2016). Head lice do not fly or jump, rather transmit from infested person to intact ones through direct head to head contact or less frequently indirectly via sharing combs, clothes, towels and blankets and other belongings (Devore et al., 2015). Head lice are not considered to be source of pathogen transmission, however, the parasite saliva and fecal antigen cause severe pruritus and sensitization of the scalp (Wooltorton, 2003). Secondary bacterial infection at the bite site is considered as common complication especially during constant infestations (Mazurek and Lee, 2000), and in very severe infestation, head lice may cause anemia (Guss et al., 2011). There are other studies carried out on head lice in Iraq and the prevalence of the parasite varies according to locations, time of the study, age and sex of the hosts (AlAlousi and Tawfeeq, 2007; Hamad, 2012; AlMarjan and Kamil, 2014; Suleiman and Magar, 2014; Obaid, 2018). The psychological impacts of head lice on child ren are not well studied. Sleeping disturbance, itching, restlessness, depression, attention deficit in the class, insomnia, lack of social status and psychological stress caused by stigmatization by peers are all factors expected to cause anxiety which might indirectly affect the learning performance of children and eventually result in educational failure (Mumcuoglu, 1991; Andrews and Wilding, 2004; Tebruegge et al., 2011; Devore and Schutze 2015). The current study aimed to investigate the prevalence of $P$. humanus capitis in children from primary schools in Kalar district and their relation with anxiety of children.

\section{Materials and Methods}

A sample of 8847 primary school children from 22 primary schools in Kalar district and two sub-districts (Rizgari and Girdagozina), Kurdistan region of Iraq were investigated for the prevalence of head lice, Pediculus huumanus capities (Figure 1).

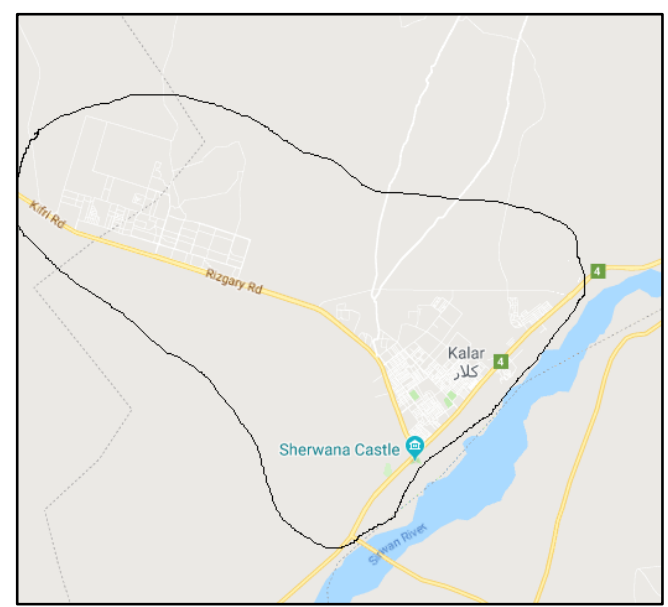

Figure 1: Study area, Kalar-Kurdistan region, Iraq

The children aged 6-11 years and consisted of (4410) boys and (4437) girls. The screening for the parasites was carried out by using finetoothed combs and visual inspection of the scalp was performed to find adult lice, ny mph and eggs (Khidhir et al., 2017). A questionnaire form was filled out about different variables of the children such as age, sex, number of children in class, hair color, hair type, hair length, method of transportation, and number of family members. To study anxiety in children, a questionnaire form was developed based on the literature review and (GAD 7) scales for measuring Anxiety among youth (Spitzer et al., 2006; Muris et al., 2017). Then, the questionnaire was shown to five university professors in the area of education and psychology. After receiving experts' feedback, the final version of the questionnaire was randomly distributed over 859 primary school children who were infested with head lice. Parents of the children filled the questionnaires. The questionnaire had items on indicators of variables to demand the opinion of participants. The statements formed questionnaire created answers, which were tabulated on four scales, consisting of not at all, several days, more than half days and nearly every day. Cronbach's Alpha was used to examine the reliability of the 
questionnaire. It resulted in 0.806, which is very acceptable. Variables of the study were statistically analyzed using Graphpad prism software version 6.1. The differences between variables were considered significant at $5 \%$ level of significance $(p<0.05)$.

\section{Results}

The overall prevalence of head lice infestation among school children in this study was $14.43 \%(1277 / 8847)$ and was significantly higher in girls $24 \%(1065 / 4437) \mathrm{p}<0.05$ than boys $4.8 \%(212 / 4410)$. The highest rate of infection was observed in children aged 10-11 years $(23.35 \%)$, while the lowest prevalence of the parasite was observed in children aged 6-7 years $(8.73 \%)$, and there was a significant differences between infection rates among the different age groups $p<0.05$. Infections were recorded in all the 22 investigated schools, the highest rate of infection was observed in Shakal school $44.44 \%$ while the lowest was in Ashna $4.72 \%$ and there was a significant difference between infection rates in the studied schools $\mathrm{p}<0.05$. There was a significant correlation between student number in class and infection rate $\mathrm{p}<0.05$. Infection rate was significantly higher in Kalar center $(15.44 \%)$ in compare to that of the subdistricts $(13.56 \%) \mathrm{p}<0.05$. The result of the study showed that $66 \%$ of the infested children had moderate an xiety. There was also a significant difference between gender and level of anxiety. However, no significant difference was observed between level of anxiety and age groups.

Table 1: Prevalence of head lice in boys and girls of primary schools in Kalar district

\begin{tabular}{llll} 
Gender & $\begin{array}{l}\text { Examined } \\
\text { children }\end{array}$ & $\begin{array}{l}\text { Infected } \\
\text { children }\end{array}$ & $\begin{array}{l}\text { Infection } \\
\text { rate \% }\end{array}$ \\
\hline Boys & 4410 & 212 & 4.8 \\
Girls & 4437 & 1065 & 24 \\
Total & 8847 & 1277 & 14.43 \\
P=0.0001 & & &
\end{tabular}

Table 2: Prevalence of head lice among primary schoolchildren in Kalar district according to age groups

\begin{tabular}{llll}
$\begin{array}{c}\text { Age } \\
\text { groups }\end{array}$ & $\begin{array}{c}\text { Samples } \\
\text { examined }\end{array}$ & $\begin{array}{c}\text { No. } \\
\text { infected }\end{array}$ & $\begin{array}{c}\text { Infection } \\
\text { rate } \%\end{array}$ \\
\hline 6-7 years & 3010 & 263 & 8.73 \\
8-9 years & 2943 & 338 & 11.48 \\
10-11 & 2894 & 676 & 23.35 \\
years & & &
\end{tabular}

$$
\mathrm{P}=0.0001
$$

Table 3: Prevalence of head lice in school children in Kalar and its sub-districts

\begin{tabular}{llll}
$\begin{array}{c}\text { Location } \\
\text { of school }\end{array}$ & $\begin{array}{c}\text { Examined } \\
\text { children }\end{array}$ & $\begin{array}{c}\text { Infected } \\
\text { children }\end{array}$ & $\begin{array}{c}\text { Infection } \\
\text { rate \% }\end{array}$ \\
\hline $\begin{array}{l}\text { Kalar } \\
\text { center }\end{array}$ & 4040 & 624 & 15.44 \\
$\begin{array}{l}\text { Sub- } \\
\text { districts }\end{array}$ & 4807 & 652 & 13.56
\end{tabular}

$$
\mathrm{P}=0.0132
$$

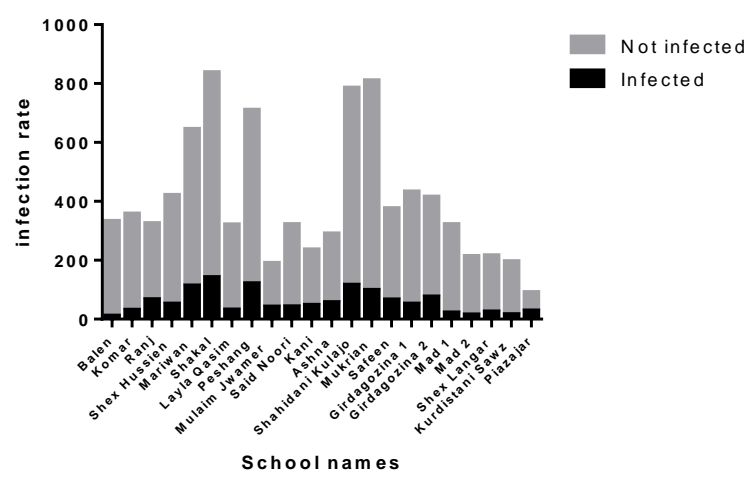

Figure 2: Infection rates with head lice in different primary schools in Kalar and other sub-districts

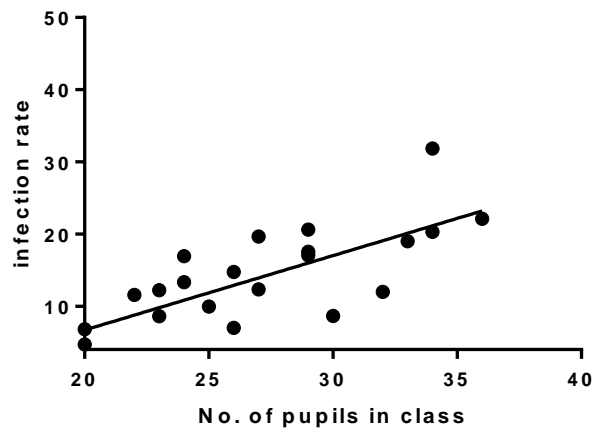

Figure 3: Correlation between number of students in class and infection rate 
Table 4: Reliability of the study questionnaire

\begin{tabular}{ccc}
$\begin{array}{c}\text { Cronbach's } \\
\text { Alpha }\end{array}$ & $\begin{array}{c}\text { Cronbach's Alpha } \\
\text { Based on } \\
\text { Standardized Items }\end{array}$ & No. of Items \\
\hline 0.804 & 0.806 & 7
\end{tabular}

Table 5: Levels of anxiety among infested children

\begin{tabular}{|c|c|c|c|c|c|}
\hline & & 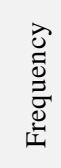 & 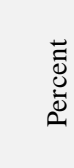 & 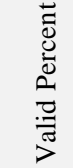 & 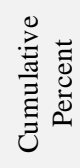 \\
\hline \multirow[t]{4}{*}{ Valid } & $\begin{array}{l}\text { Minimal } \\
\text { anxiety }\end{array}$ & 281 & 32.7 & 32.7 & 32.7 \\
\hline & $\begin{array}{l}\text { Moderate } \\
\text { anxiety }\end{array}$ & 569 & 66.2 & 66.2 & 99.0 \\
\hline & $\begin{array}{l}\text { Sever } \\
\text { anxiety }\end{array}$ & 9 & 1.0 & 1.0 & 100.0 \\
\hline & Total & 859 & 100.0 & $\begin{array}{r}100 . \\
0\end{array}$ & \\
\hline
\end{tabular}

Table 6: Correlations between gender and levels of anxiety

\begin{tabular}{ccccc} 
Gender & $\begin{array}{c}\text { Mevel of anxiety } \\
\text { Minim } \\
\text { al } \\
\text { anxiety }\end{array}$ & $\begin{array}{c}\text { Moderat } \\
\text { e anxiety }\end{array}$ & $\begin{array}{c}\text { Severe } \\
\text { anxiety }\end{array}$ & Total \\
\hline Male & 33 & 102 & 0 & 135 \\
Female & 248 & 467 & 9 & 724 \\
& $\mathrm{P}=0.0284$ & & 859
\end{tabular}

Table 7: Correlation between age groups and levels of anxiety

\begin{tabular}{|c|c|c|c|c|}
\hline \multirow{2}{*}{$\begin{array}{l}\text { Age } \\
\text { groups }\end{array}$} & \multicolumn{3}{|c|}{ Level of anxiety } & \multirow[t]{2}{*}{ Total } \\
\hline & $\begin{array}{c}\text { Minimal } \\
\text { anxiety }\end{array}$ & $\begin{array}{c}\text { Moderate } \\
\text { anxiety }\end{array}$ & $\begin{array}{l}\text { Severe } \\
\text { anxiety }\end{array}$ & \\
\hline $6-7$ years & 58 & 134 & 2 & 194 \\
\hline $8-9$ years & 63 & 155 & 3 & 221 \\
\hline $\begin{array}{l}10-11 \\
\text { years }\end{array}$ & 160 & 280 & 4 & 444 \\
\hline Total & 281 & $\begin{array}{c}569 \\
.3002\end{array}$ & 9 & 859 \\
\hline
\end{tabular}

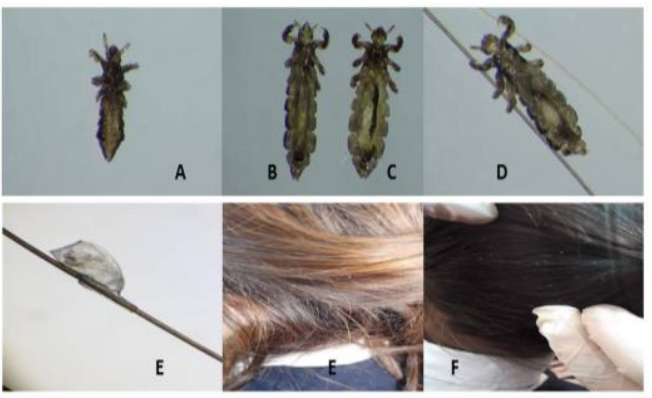

Figure 4: Morphological views of the different stages of head lice $P$. humanus capitis and infestation sites. A- Dorsal view of nymph, BVentral veiw of adult female, C- Ventral view of adult male, D- Male head lice attached to human hair shaft, E-Egg (Nits) of head lice, D,E infested children with adults and ny mphs of head lice.

\section{Discussion}

In the present study, we investigated (22) primary schools in Kalar district and two subdistricts: Rizgari and Girdagozina to study the prevalence of head lice $P$. humananus capitis among primary school children. An overall 8847 children were investigated for head lice infestation and the rate of infestation was $14.43 \%$. National pediculosis association of USA defines pediculosis as epidemic when the rate of infestation is greater than 5\% (Rassami and Soonwera, 2012). Head lice are cosmopolitan which infest children and adults in all over the world. In the A mericas, most of the studies are carried out in the South American countries. However, it is estimated that 6-12 million children between the ages of 3-11 become infested with head lice each year in the US (CDC, 2015). In Brazil, the prevalence of head lice in school children and day-care centers was $18.5 \%$ (Borges-Moroni et al., 2011). Higher rate (29.7\%) was reported in Argentina when 1856 elementary school children aged 3-13 were screened for head lice (Toloza et al., 2009). In Nigeria, Okoh and Alikor (2013) carried out a similar study and the prevalence of head lice was very low $(0.7 \%)$ compared to the current study. However, in Egypt the rate of infestation in primary school children was $33 \%$ using 
dermoscopic examination (El-Sayed et al., 2017). In Australia the prevalence of head lice was 13\% (Counahan et al., 2004). In Turkey, two studies were carried out on primary school children in Sivas and Kayseri and the prevalence of head lice were $6 \%$ and $13.1 \%$ respectively (Deg erli et al., 2012; Gulgun et al., 2013). In Iran which is the closest nonIraqi area to Garmian region, the prevalence of head lice in primary school children varies from $0.47 \%$ to $67.3 \%$ (Doroodgar et al., 2011; Soleimani-Ahmadi et al., 2017). In Iraq, during the last 15 years there are noticeable studies carried out on the prevalence of head lice, the biology and methods of prevention and control of the parasite and various infection rates have been reported. Mahmood (2010) investigated children from 10 primary school aged 6-12 years in the Iraqi capital Baghdad, the researcher reported prevalence of $13.5 \%$. Earlier in Nassiryia Province lower prevalence of head lice was reported among primary school children $7.2 \%$ (Al-Aboody, 2008). In Mosul, pupils from 24 primary schools were screened for head lice; it was found that $33.2 \%$ of the children were infested with the parasite (Al-Abaddy, 2008). In Najaf and Erbil, head lice infestation was close to the findings of the present study $14 \%$ and 14.52\% (Khidhir et al., 2017; Salih et al., 2017). In Diyala, higher rate was reported $24 \%$ compared to ours when primary school children from three areas of the governorate (Baquba, Buhrz and Baladroz) were investigated for infestation with the parasite (Salih, 2010).

In the current study the infection rate with head lice was significantly greater in girls compared to boys. This finding is in agreement with those of most of the literature reported in Iraq and the world (Counahan et al., 2004; Toloza et al., 2009; Al-Marjan and kamil, 2014; Suleiman and Magar, 2014). The main reason for the higher lice rate in girls is the presence of dense and long hair which provides a better shelter for the parasite to climb without being easily noticed (Khidhir et al., 2017). The higher infestation rate was observed in in the age group 10-11 in the current study compared to the younger groups 6-7 and 8-9 years. This is in accordance with the studies of (Borges-Moroni et al., 2011; ElSayed et al., 2017). However, other researchers have reported that younger children particularly the age 6-7 are more infested than older children (Salih, 2010; Khidhir et al., 2017). The reason for the higher prevalence of infestation in older children in the present study could be due to that children at this age are more selfdependent in contrast to the younger child ren who depend on their parents particularly at bath time. Prevalence of head lice varied significantly from school to school in the current study. The reason for this variation is due to the variation in parental and health advisors care and control strategies applied in different areas (Toloza et al., 2009). Lice infestation had direct relationship with the number of student in class. The reason for that is attributed to that crowded classes minimize the distance between pupils and during class activities there is higher physical contact between children, hence increasing the prevalence rate (Gharsan et al., 2016).

Previously, head lice were a hygiene issue mainly linked to students from a low socioeconomic background. Nowadays, head lice are observed among students from all socioeconomic status. Head lice cause different stigmas among students. Parents and children are ashamed and experience high level of an xiety when they realize themselves or their children are infested with head lice (Mumcuoglu, 1999; Devore and Schutze, 2015; Lacarrubba et al., 2019). Therefore, the other main purpose of this study was to determine the possible psychological effects such as anxiety caused by head lice on the infested pupils. The results of the present study showed that $66 \%$ of the school children, who had head lice, experienced moderate anxiety. The findings of this study align with Mumcuoglu's study. While, the outcome of 
head lice is significant for everyone, it is more dangerous in children According to Mumcuohlu, head lice in kindergarten children was associated with fear and an xiety (1991). In addition, the A merican Academy of Pediatrics reported that majority of the school age children who have head lice suffer from high level of anxiety (Devore and Schutze 2015). Anxiety is a psychological disorder that affects individual's life dramatically. Previous research reported that the prevalence of anxiety a mong girls is higher than boys (Gater et al., 1998). A person with anxiety is described as "predisposed to experiencing excessive fear and/or anxiety responses to perceived threats in a way that leads to significant distress and impairment in functioning" (Craske and Stein, 2016). Finding the relationship between anxiety and students' performance has been the focus of the researchers. Results of previous studies have shown that anxiety has a direct impact on the students' academic performance at school (Andrews and Wilding, 2004). Students who experience anxiety perform poorly in academic tasks.

Although there are several factors that affect anxiety levels, fear is one of the fundamental elements of all the anxiety disorders (Clark and Beck, 2011). Parents of the students who have participated by filling out the questionnaire indicated that their children fear being exposed for having head lice. In other words, students who had ever been infected with head lice could be subject of Bully ing (Tebruegge et al., 2011). Finding the relationship between gender and level of the anxiety was another objective of this study. The results of the current study showed that there was a significant difference between gender and level of anxiety. Essentially, several researches have stated that girls are more prone to experience anxiety than their boy counterparts (Toufexis et al., 2006; Lewinsohn et al., 1998; McLean et al., 2011; Park and French, 2013).
Finally, the current research attempted to investigate the relationship between the level of anxiety and the student's age group. The statistical findings of this study demonstrated no significant relationship between level of anxiety and age groups. On the other hand, results of numerous studies suggest that there is a relationship between age-group and anxiety disorder. Reportedly, "older persons have significantly lower frequencies of any current anxiety disorder and any lifetime anxiety disorder, even after controlling for relevant demographic and clinical variables" (Flint et al., 2010). Similarly, Byers et al. (2010) stated that with age anxiety generally starts to decline. The absence of significant relationship between level of anxiety and age groups in the present study could be because the range of age groups were very close to each other, (6-7,8-9,10-11) years old.

\section{Conclusions}

The present study concludes that head lice are common in primary school children of Kalar district to the epidemic level. They infect both genders with higher rate in girls than boys. Some schools have high rate of infection than others. Children aged 10-11 more frequently carry the parasite. The more crowded the places the higher rate of infection is expected. In addition, the findings of the study showed that majority of the infested children experience moderate anxiety. It is therefore, better care is required from health directorate, school administrations and parents to minimize the rate of infestation.

\section{Acknowledgments}

Authors wish to express their sincere thanks to the staffs of Kalar health self-preservation station especially Mr. Mohammed Sattar, Directorate of education in Kalar, the school principals in Kalar, Rizgary and Girdagozina for their great cooperation. 


\section{References}

1.Akhter S., Mondal M.M., Alim M.A. and Moinuddin M.A. (2010). Prevalence of lice infestation in humans in different socioeconomic status at mymensingh in bangladesh. Int. J. Bio. Res. 1(1): 13-17.

2.Al-Abaddy A. I. (2008). Investigation on the incidence of infection of lice among human goats and sheep in Mosul city-Iraq. 1-7

3.Al-Aboody B.A. (2008). Prevalence of head lice (Pediculus humanus capitis) among primary schools pupils in Nassirya city. Omsalama Journal of Sciences. 5(2), 207-210.

4.Al-Alousi T.I. and Tawfeeq A.E. (2007). Prevalence of the (head louse) Pediculus humanus capitis among pupils in Tikrit city and neighbors.

5.Al-Marjan K.S. and Kamil F.H. (2014). Survey for Pediculus humanus capitis De Geer (Pediculidae: Phthiraptera: Insecta) Among Primary Schools Children in Erbil City. AlMustansiriy ah J. Sci. 25(2): 25-30.

6.Amin O.M. and Ameen N.M. (2018). Incidence of Phthiriasis palpebrarum caused by pubic lice Pthirus pubis in Al-Sulaimaniyah province, Kurdistan region, Iraq. Journal of Garmian University. 5(2): 41-47.

7.Andrews B. and Wilding J. M. (2004). The relation of depression and anxiety to life-stress and achievement in students. British journal of psychology, 95(4): 509-521.

8.Borges-Moroni R., Mendes J., Justiniano S. and Binda A. (2011). Head lice infestation in children in day-care centers and schools of Manaus, Amazon, Brazil. Revista De Patologia Tropical. 40 (3): 263-270.

9.Byers A. L., Yaffe K., Covinsky K. E., Friedman M. B. and Bruce M. L. (2010). High occurrence of mood and anxiety disorders among older adults: The National Comorbidity Survey Replication. Archives of general psychiatry, 67(5): 489-496.

10. Centers for disease control and prevention (2015). Global Health, Division of Parasitic Diseases. Available online at: https://www.cdc.gov/parasites/lice/head/gen_info /faqs.html

11. Clark D. A. and Beck A. T. (2011). Cognitive therapy of anxiety disorders: Science and practice. Guilford Press.

12. Counahan M., Andres R., Büttner P., Byrnes G. and Speare R. (2004). Head lice prevalence in primary schools in Victoria, Australia. J. Paediatr. Child Health. 40: 616-619.

13. Craske M.G. and Stein. (2016) Anxiety. Lancet. 388: 3048-3059.

14. Deg erli S., Malatyali, E., Celiksoz A. Ozcelik S. and Mumcuoglu K. (2012). The Prevalence of Pediculus humanus capitis and the Coexistence of Intestinal Parasites in Young Children in Boarding Schools in Sivas, Turkey. Pediatric Dermatology. 29(4): 426-429.

15. Devore C.D., Schutze G.E. and the council on school health and committee on infectious diseases. (2015). Head lice. Pediatrics.135, e1355.

16. Devore, C. D. and Schutze, G. E. (2015). Head Lice. Pediatrics, 135(5).

17. Doroodgar A., Sadr F., Sayyah M., Doroodga M., Tashakkor Z. and Doroodgar M. (2011). Prevalence and associated factors of head lice infestation among primary school children in city of Aran and Bidgol (Esfahan Province, Iran), 2008. Payesh, Journal of The Iranian Institute For Health Sciences Research. 10(4): 439-447.

18. El-Sayed M.M., Toama M.A., Abdelshafy A.S., Esawy A.M. and El-Naggar S.A. (2017). Prevalence of pediculosis capitis among primary school students at Sharkia Governorate by using dermoscopy. Egypt J. Dermatol. 37: 33-42.

19. El-Sayed M.M., Toama M.A., Abdelshafy A.S., Esawy A.M. and El-Naggar S.A. (2017). Prevalence of pediculosis capitis among primary school students at Sharkia Governorate by using dermoscopy. Egyptian Journal of Dermatology and Venereology. 37: 33-42.

20. Flint A. J., Peasley-Miklus C., Papademetriou E., Meyers B. S., Mulsant B. H., Rothschild A. J. and STOP-PD Study Group. (2010). Effect of age on the frequency of anxiety disorders in major depression with psychotic features. The American Journal of Geriatric Psychiatry, 18(5): 404-412.

21. Gater R., Tansella M., Korten A., Tiemens B. G., Mavreas V. G. and Olatawura, M. O. (1998). Sex differences in the prevalence and detection of depressive and anxiety disorders in general health care settings: report from the World Health Organization Collaborative Study on Psychological Problems in General Health Care. Archives of general psychiatry, 55(5): 405413. 
22. Gharsan F.N., Abdel-Hamed N.F., Elhassan S.A. and Gubara N.G. (2016). The prevalence of infection with head lice Pediculus humanus capitis among elementary girl students in Albaha region-Kingdom of Saudi Arabia. Int. J. Res. Dermatol. 2(1):12-17.

23. Gulgun M., Balcı E., Karaoğlu A, Babacan O. and Türker T. (2013). Pediculosis capitis: prevalence and its associated factors in primary school children living in rural and urban areasin Kayseri, Turkey. 21 (2): 104-108.

24. Guss D.A., Koenig M. and Castillo E.M. (2011) Severe iron deficiency anemia and lice infestation. J. Emerg. Med. 41(4): 362-265.

25. Hamad, S.K. (2012). Epidemiology of head lice and human scabies mite in Erbil governorate-Kurdistan region-Iraq. Msc. Thesis College of Agriculture, University of Salahaddin - Erbil . 117 P.

26. Khidhir K.N., Mahmood C.K. and Ali W.K. (2017). Prevalence of infestation with head lice Pediculus humanus capitis (De Geer) in primary schoolchildren in the centre of Erbil city, Kurdistan region, Iraq. Pak. Entomol. 39(2): 1-4.

27. Lacarrubba F., Verzì A., E and Micali G. (2019) Trichoscopy in the Differential Diagnosis of Pseudonits. Skin Appendage Disord .5:142145.

28. Lewinsohn P. M., Gotlib I. H., Lewinsohn M., Seeley J. R. and Allen N. B. (1998). Gender differences in anxiety disorders and anxiety symptoms in adolescents. Journal of abnormal psychology, 107(1): 109.

29. Mahmood S.A. (2010). Head pediculosis among in Baghdad area elementary schoolchildren. Iraqi Journal of Science. 51(1): 49-55.

30. Mazurek C.M. and Lee N.P. (2000). How to manage head lice. Wjm. 172: 342-345.

31. McLean C. P., Asnaani A., Litz B. T. and Hofmann S. G. (2011). Gender differences in anxiety disorders: prevalence, course of illness, comorbidity and burden of illness. Journal of psychiatric research, 45(8): 1027-1035.

32. Meister L. and Ochsendorf F. (2016). Head lice. Epidemiology, Biology, Diagnosis, and Treatment. Dtsch Arztebl Int. 113: 763-772.

33. Mumcuoglu K. Y. (1991). Head lice in drawings of kindergarten children. Isr. J. Psy chiatry Relat. Sci, 28(1): 25-32.

34. Mumcuoglu K. Y. (1999). Prevention and treatment of head lice in children. Pediatric Drugs, 1(3): 211-218.
35. Muris, P., Simon, E., Lijphart, H., Bos, A., Hale, W., \& Schmeitz, K. (2017). The youth anxiety measure for DSM-5 (YAM-5): development and first psychometric evidence of a new scale for assessing anxiety disorders symptoms of children and adolescents. Child Psychiatry \& Human Development, 48(1): 1-17.

36. Obaid H.M. (2018). Home remedies for Pediculus humanus capitis infection among schoolchildren. Our Dermatol. Online. 9(2):131136.

37. Okoh B.A. and Alikor E.A. (2013). Prevalence of head lice infestation in primary school children in Port Harcourt. East African Medical Journal. 90(8): 269-274.

38. Park G. P. and French B. F. (2013). Gender differences in the foreign language classroom anxiety scale. Sy stem, 41(2): 462-471.

39. Rassami W. and Soonwera M. (2012). Epidemiology of pediculosis capitis among schoolchildren in the eastern area of Bangkok, Thailand. Asian Pac J Trop Biomed. 2(11): 901904.

40. Salih H.A., Shamran S.J. and Al-Shimery D.F. (2017). Prevalence of pediculosis capitis (head lice) and treating among children in AlNajaf city, IRAQ. Al-Kufa University Journal for Biology. 9(3): 179-183.

41. Salih W.M. (2010). STUDY ON Pediculus humanus capitis De Geer 1767 among some primary schools pupils in Diyala Province. Journal of Kerbala University. 8(1): 334-340.

42. Soleimani-Ahmadi M., Jaberhashemi S., Zare M. and Sanei-Dehkordi A. (2017). Prevalence of head lice infestation and pediculicidal effect of permethrine shampoo in primary school girls in a low-income area in southeast of Iran. BMC Dermatology.17(10): 1-6.

43. Spitzer, R. L., Kroenke, K., Williams, J. B., \& Löwe, B. (2006). A brief measure for assessing generalized an xiety disorder: the GAD7. Archives of internal medicine, 166(10): 10921097.

44. Suleiman A.K. and Magar E.A. (2014). Study of Distribution of Head Lice Pedicalus humanus Among The Students of Many Primary School in Kirkuk Province Pediculus humanus capitis De Geer ( Anoplura : Pediculidae ). Tikrit Journal of Pure Science. 19(6): 1-6.

45. Tebruegge M., Pantazidou A. and Curtis N. (2011). What's bugging you? An update on the treatment of head lice infestation. Archives of 
Disease in Childhood-Education and Practice, 96(1): 2-8.

46. Toloza A., Vassena C., Gallardo A., González-Audino P. and Picollo M.I. (2009). Epidemiology of Pediculosis capitis in elementary schools of Buenos Aires, Argentina. Parasitol Res. 104:1295-1298.
47. Toufexis D. J., Myers K. M. and Davis M. (2006). The effect of gonadal hormones and gender on anxiety and emotional learning. Hormones and behavior, 50(4): 539549.

48. Wooltorton E. (2003). Concerns over lindane treatment for scabies and lice. Canadian Medical Association or its licensors. 168(11): 1447-1448. 